\title{
The Inclusion Compound of a New Ionizable Derivative of $\beta$-Cyclodextrin with Ferrocenium Drug
}

\author{
Chang-Sheng Lu, Xiao-Ming Ren, Chuan-Jiang Hu, Hui-Zhen Zhu, and Qing-Jin Meng* \\ Coordination Chemistry Institute, State Key Laboratory of Coordination Chemistry, Nanjing University, Nanjing 210093, \\ P. R. China. Received December 22, 2000; accepted February 23, 2001
}

A new $\beta$-cyclodextrin $(\beta$-CD) derivative, mono[6-deoxy-6-(2-butenedinitrile-2,3-dimercapto sodium salt)]- $\beta$ CD (6-mnt- $\beta-C D)$, and its inclusion compound with a ferrocenium drug, have been prepared and characterized by IR, UV, ${ }^{13} \mathrm{C}-\mathrm{NMR}$ spectroscopy, and mass spectrometry, elemental analysis, thermogravimetry, and cyclic voltammetry $(\mathrm{CV})$. The interplay between the side-arm anion of $\beta$-CD and the ferrocenium (guest) in the inclusion compound 6-mnt- $\beta-\mathrm{CD}^{-} / \mathrm{Fc}^{+}$has been investigated by ${ }^{13} \mathrm{C}-\mathrm{NMR}, \mathrm{UV}$, IR, and thermogravimetric methods. Charge transfer from the anion to the cation in $6-\mathrm{mnt}-\beta-\mathrm{CD}^{-} / \mathrm{Fc}^{+}$was then experimentally identified. The interaction between the guest and the host with side-arm in $6-\mathrm{mnt}-\beta-\mathrm{CD}^{-} / \mathrm{Fc}^{+}$resulted in smaller positive potential shifts compared to that in the inclusion compound $\left[\beta-\mathrm{CD} / \mathrm{Fc}^{+}\right] \mathrm{BF}_{4}^{-}$.

Key words mono[6-deoxy-6-(2-butenedinitrile-2,3-dimercapto sodium salt)]- $\beta$-cyclodextrin; ferrocenium tetrafluoroborate; inclusion compound; $\beta$-cyclodextrin; differential thermogravimetry; cyclic voltammetry

Antitumor activities of the ferrocenium complexes were detected in 1984 against Enrlich ascites tumor. ${ }^{1)}$ These cytostatically active agents exhibited broad-spectrum antiviral properties in vivo and in vitro. ${ }^{2}$ They have also shown antiproliferative activities against Sarcoma 180, B16 melanoma, Colon 38, MCH-11, P-815, and Rauscher virusinduced leukemia, ${ }^{3)}$ as well as against human adenocarcinoma, squamous cell carcinoma, and large-cell carcinoma of the lung. ${ }^{4)}$

Inclusion complexation of cyclodextrins (CDs) with drugs can improve certain properties of the drugs such as solubility, stability, and bioavailability. ${ }^{5)}$ The enhancement of drug activity and selective transfer or the reduction of side effects can also be achieved by inclusion compound formation. ${ }^{6,7)}$ Herein we report for the first time the inclusion compounds of the ferrocenium drug (ferrocenium tetrafluoroborate, $\mathrm{FcBF}_{4}$ ) with $\beta$-CD and a derivative of $\beta$-CD (mono[6-deoxy6-(2-butenedinitrile-2,3-dimercapto sodium salt)]- $\beta$-CD, 6mnt- $\beta$-CD). The thermal stability and the interaction between host and guest in these inclusion compounds were investigated.

\section{Experimental}

General Methods A Bruker IFS66V FT-IR spectrophotometer was used, and the measurements were made by the $\mathrm{KBr}$ disk method. The UV spectra were recorded on a Shimadzu UV-3100 spectrometer. The mass spectra were performed on a Finnigan mat APISSQ-710 mass spectrometer. All ${ }^{13} \mathrm{C}$ - and ${ }^{1} \mathrm{H}-\mathrm{NMR}$ spectra were recorded on a Bruker AVANCE-300 spectrometer in dimethyl sulfoxide- $d_{6}$ (DMSO- $d_{6}$ ) solution at $15^{\circ} \mathrm{C}$. Elemental analysis was determined by a Perkin-Elmer $240 \mathrm{C}$ elemental analyzer. Thermogravimetric (TG) analysis curves were recorded on an American SDT-2960 thermal analyzer. Cyclic voltammetry (CV) was done with an EG\&G model 273 instrument in $N, N$-dimethylformamide (DMF) solution. The three-electrode electrochemical cell used was equipped with a platinum disc working electrode, a platinum auxiliary electrode, and a $\mathrm{Ag} / \mathrm{AgCl}$ reference electrode. Ethanol was of an analytically pure grade. DMF was distilled under reduced pressure in an $\mathrm{N}_{2}$ atmosphere before use. 2-Butenedinitrile2,3-dimercapto disodium salt $\left(\mathrm{Na}_{2} \mathrm{mnt}\right)$, mono-(6- $O$-tolylsulfonyl)- $\beta$ - $\mathrm{CD}$ (6Ots- $\beta$ - $\mathrm{CD}$ ) and $\mathrm{FcBF}_{4}$ were synthesized according to the methods described in the literature. ${ }^{8-10)}$

Synthesis of 6-Mnt- $\boldsymbol{\beta}$-CD To a solution of $\mathrm{Na}_{2} \mathrm{mnt}(0.2 \mathrm{~g}, 1.08 \times$ $\left.10^{-3} \mathrm{~mol}\right)$ in water $(30 \mathrm{ml})$ was added $6-O t s-\beta$-CD $\left(0.5 \mathrm{~g}, 0.39 \times 10^{-3} \mathrm{~mol}\right)$, and the mixture was stirred at $65^{\circ} \mathrm{C}$ for $3-4 \mathrm{~h}$ under an $\mathrm{N}_{2}$ atmosphere. After cooling down to room temperature, the yellow solution was concentrated. Then the dark-red residue (about $3-4 \mathrm{ml}$ ) was added in drops to stirred ethanol $(120 \mathrm{ml})$ to precipitate $0.4 \mathrm{~g}$ crude 6 - $\mathrm{mnt}-\beta$-CD. The crude product was dissolved in $1 \mathrm{ml}$ of water, and was then added in drops to stirred ethanol $(10 \mathrm{ml})$ again. After standing overnight, the final product would precipitate from the ethanol solution as a yellow powder. ${ }^{13} \mathrm{C}$-NMR $\left(\right.$ DMSO- $\left.d_{6}\right) \delta$ : $59.94,72.12,72.49,73.15,80.94,81.15,81.62,102.05$, 118.38, 118.79. IR $(\mathrm{KBr}) \mathrm{cm}^{-1}:$ 2189.7. UV $\lambda_{\max }\left(\mathrm{H}_{2} \mathrm{O}\right) \mathrm{nm}(\log \varepsilon): 371$ (3.94). UV $\lambda_{\max }$ (DMF) nm $(\log \varepsilon): 385.5$ (3.96). MS m/z: 1258.0 [Calcd for $\mathrm{C}_{46} \mathrm{H}_{69} \mathrm{~N}_{2} \mathrm{O}_{34} \mathrm{~S}_{2}\left([\mathrm{M}-\mathrm{Na}]^{-}\right)$: 1258.2]. Anal. Calcd for $\mathrm{C}_{46} \mathrm{H}_{69} \mathrm{~N}_{2} \mathrm{NaO}_{34} \mathrm{~S}_{2}$. $8 \mathrm{H}_{2} \mathrm{O}: \mathrm{C}, 38.76 ; \mathrm{H}, 6.01 ; \mathrm{N}, 1.97$. Found: C, 38.85; H, 6.21; N, 2.08 .

Preparation of the Inclusion Compounds of Ferrocenium Drug The inclusion compound of 6-mnt- $\beta$-CD with $\mathrm{FcBF}_{4}\left(6-\mathrm{mnt}-\beta-\mathrm{CD}^{-} / \mathrm{Fc}^{+}\right)$was prepared by the coprecipitation method. ${ }^{11)} 0.53 \times 10^{-3} \mathrm{Mol}$ of 6 -mnt- $\beta$-CD was dissolved in $50 \mathrm{ml}$ of water, and then $1.06 \times 10^{-3} \mathrm{~mol}$ of $\mathrm{FcBF}_{4}$ was added to the aqueous solution. After stirring at $60^{\circ} \mathrm{C}$ for $2 \mathrm{~h}$, the solution was cooled down to room temperature and yielded a dark yellow solid precipitate. It was then collected by filtration and washed twice with water and ethanol. Finally, drying of the solid in air for $4 \mathrm{~h}$ yielded the inclusion compound as a pale brown solid. The inclusion compound of $\beta$-CD with $\mathrm{FcBF}_{4}$ was prepared in the same way.

\section{Results and Discussion}

The New Host 6-Mnt- $\boldsymbol{\beta}$-CD Both the electron spectrum and the IR spectrum analyses of 6 -mnt- $\beta$-CD have shown the presence of the mnt group in the compound (see the Experimental). Moreover, electro-spray MS provided structure evidence of the existence of mnt-modified $\beta$-CD $(\mathrm{m} / \mathrm{z}$ 1258.0, see the Experimental). In addition, ${ }^{13} \mathrm{C}-\mathrm{NMR}$ spectrum of the host molecule (6-mnt- $\beta$-CD) showed the resonances due to one $\mathrm{C}=\mathrm{C}$ bond at $\delta 118.38$ and $118.79 \mathrm{ppm}$, and two nitrile groups at $\delta 80.94$ and $81.15 \mathrm{ppm}$ (Table 1). The prominent upfield shift of the signal of C-6 $(-0.08 \mathrm{ppm}$, Table 1$)$ in ${ }^{13} \mathrm{C}-\mathrm{NMR}$ spectrum of $6-\mathrm{mnt}-\beta-\mathrm{CD}$, compared to that of pure $\beta-\mathrm{CD}$, was observed. The upfield shift was considered to result mainly from the introduction of electron-rich mnt onto the $\beta$-CD rim. ${ }^{12)}$ Figure 1 showed thermogravimetric (TG) and differential TG (DTG) curves of $6-O t s-\beta-\mathrm{CD}, \mathrm{Na}_{2} \mathrm{mnt}$, and $6-\mathrm{mnt}-\beta-\mathrm{CD}$. Two peaks were observed in the DTG curve of the hydrate 6 -Ots- $\beta$-CD (curve $\mathrm{a}^{\prime}$ ). The first peak (around $59^{\circ} \mathrm{C}$ ) corresponded to the dehydration process, and the other (around $185^{\circ} \mathrm{C}$ ) was related to the degradation of the 6 -Ots- $\beta$-CD structure. In the case of $\mathrm{Na}_{2} \mathrm{mnt}$ (curve $\mathrm{b}^{\prime}$ ), peaks of the desolvation and decomposition were clearly seen (at around $48{ }^{\circ} \mathrm{C}$ and $98^{\circ} \mathrm{C}$, respectively). However, in that of 6 -mnt- $\beta$-CD (curve $\mathrm{c}^{\prime}$ ), no obvious signals were 
Table 1. Data of ${ }^{13} \mathrm{C}-\mathrm{NMR}$ Spectra of Inclusion Compound 6-Mnt- $\beta-\mathrm{CD}^{-} / \mathrm{Fc}^{+a)}$

\begin{tabular}{|c|c|c|c|c|c|c|c|}
\hline Complex & $\mathrm{C} 1$ & $\mathrm{C} 2$ & $\mathrm{C} 3$ & $\mathrm{C} 4$ & $\mathrm{C} 5$ & $\mathrm{C} 6$ & $\mathrm{C}^{\prime}$ \\
\hline$\beta-\mathrm{CD}^{b)}$ & 102.58 & 72.67 & 73.89 & 81.94 & 72.89 & 61.17 & \\
\hline$\beta-\mathrm{CD}$ & 102.05 & 72.15 & 73.16 & 81.63 & 72.50 & 60.02 & \\
\hline 6-mnt- $\beta$-CD & 102.05 & 72.12 & 73.15 & 81.62 & 72.49 & 59.94 & $\begin{array}{l}118.38,{ }^{c)} 118.79,{ }^{c)} 80.94,{ }^{d)} \\
81.15^{d)}\end{array}$ \\
\hline$[\beta-\mathrm{CD} / \mathrm{Fc}]^{+} \mathrm{BF}_{4}^{-}$ & 102.29 & 72.17 & 73.09 & 81.80 & 72.54 & 59.96 & $67.66^{e)}$ \\
\hline $6-\mathrm{mnt}-\beta-\mathrm{CD}^{-} / \mathrm{Fc}^{+}$ & 102.16 & 72.09 & 73.01 & 81.69 & 72.43 & 59.88 & $81.42,{ }^{d)} 81.63,{ }^{d)} 67.65^{e)}$ \\
\hline
\end{tabular}

a) Relative to internal DMSO- $d_{6}(\delta=39.51 \mathrm{ppm}), \mathrm{C} 1$ to C6 refer to carbon atoms of the cyclodextrin structure. b) From reference 13 . c) Carbon atoms of the double bond in mnt. $d$ ) Carbon atoms of the nitrile group in mnt. e) Carbon atoms in the cyclopentene ring of ferrocenium.

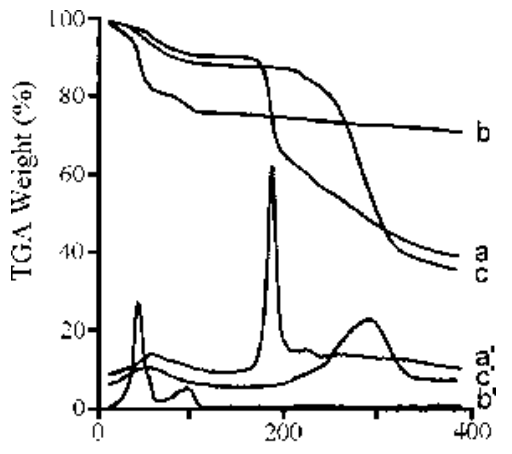

Temperature $\left({ }^{\circ} \mathrm{C}\right)$

Fig. 1. TG and DTG Curves of 6-Ots- $\beta$-CD $\left(a, a^{\prime}\right), \mathrm{Na}_{2} \mathrm{mnt}\left(\mathrm{b}, \mathrm{b}^{\prime}\right)$, and 6Mnt- $\beta$-CD (c, $\left.\mathrm{c}^{\prime}\right)$

recorded around $98^{\circ} \mathrm{C}$ and $185^{\circ} \mathrm{C}$. In addition to the dehydration occurring at around $53^{\circ} \mathrm{C}$, a new peak (around $291^{\circ} \mathrm{C}$ ) appeared clearly, which should be assigned to the decomposition of the 6-mnt- $\beta$-CD structure. Some recent studies have concentrated on the syntheses of new hydrophilic or ionizable CD derivatives and the search for their potential use as absorption enhancers or coenhancers for transmucosal absorption, ${ }^{6}$ in addition to the potential use of natural CDs in pharmaceutical fields. ${ }^{7)}$ Perhaps the new ionizable CD derivative (6-mnt- $\beta$-CD) that we have synthesized here could play a role in this area.

Inclusion Compounds of the Ferrocenium Drug Electro-spray $\mathrm{MS}$ spectra of inclusion compounds $[\beta-\mathrm{CD} /$ $\left.\mathrm{Fc}^{+}\right] \mathrm{BF}_{4}^{-}$and 6-mnt- $\beta-\mathrm{CD}^{-} / \mathrm{Fc}^{+}$have shown the presence of $\mathrm{BF}_{4}$ anion $(m / z$ 87.1) and 6-mnt- $\beta$-CD anion $(m / z 1258.1)$, respectively. It was known that in the ferrocenium inclusion compound $\left[2 \cdot \alpha-\mathrm{CD} / \mathrm{Fc}^{+}\right] \mathrm{X}^{-}$, the two $\alpha-\mathrm{CD}$ molecules are arranged head to head to form a dimer by means of intermolecular hydrogen bonding. The ferrocenium is encapsulated within the cavity of the dimer just as the ferrocene guest has done in the inclusion compound $2 \cdot \alpha-\mathrm{CD} / \mathrm{Fc}{ }^{14)}$ In the cases of $\left[\beta-\mathrm{CD} / \mathrm{Fc}^{+}\right] \mathrm{BF}_{4}^{-}$and $6-\mathrm{mnt}-\beta-\mathrm{CD}^{-} / \mathrm{Fc}^{+}$we could presume that the ferrocenium guest penetrates into $\beta$-CD cavities (as proposed in Chart 1) just as the ferrocene molecule has done in that of $\beta$-CD/Fc. ${ }^{15)}$ The stoichiometry $(1: 1$ molar ratio) of the inclusion compounds that were isolated as solid complexes in our experiments have also been confirmed by ${ }^{1} \mathrm{H}-\mathrm{NMR}$ spectroscopy (Table 2 ).

The effect of inclusion phenomenon on molecular structures of both the host and guest has been observed by ${ }^{13} \mathrm{C}$ NMR (Table 1). For example, the signal of $\mathrm{C}-1$ shifted from 102.05 to $102.29 \mathrm{ppm}$ in the inclusion compound $[\beta$ $\left.\mathrm{CD} / \mathrm{Fc}^{+}\right] \mathrm{BF}_{4}^{-}$, and from 73.15 to $73.01 \mathrm{ppm}$ for $\mathrm{C}-3$ in the in-
Table 2. Data of ${ }^{1} \mathrm{H}-\mathrm{NMR}$ Spectra of the Two Inclusion Compounds ${ }^{a)}$

\begin{tabular}{ccccccccc}
\hline \hline Complex & $\mathrm{H}-1$ & $\mathrm{H}-2$ & $\mathrm{H}-3$ & $\mathrm{H}-4$ & $\mathrm{H}-5$ & $\mathrm{H}-6$ & $\mathrm{H}^{\prime b)}$ & $\mathrm{C}_{\text {p.a. }}{ }^{c}$ \\
\hline$[\beta-\mathrm{CD} / \mathrm{Fc}]^{+} \mathrm{BF}_{4}^{-}$ & 4.84 & 3.30 & 3.65 & 3.34 & 3.60 & 3.67 & 4.17 & 1.32 \\
6-mnt- $\beta-\mathrm{CD}^{-} / \mathrm{Fc}^{+}$ & 4.84 & 3.31 & 3.66 & 3.34 & 3.58 & 3.66 & 4.17 & 1.40 \\
\hline
\end{tabular}

a) H-1 to H-6 refer to protons of the cyclodextrin structure. b) Protons in the cyclopentene ring of ferrocenium. c) Value of the comparison of peak areas of guest molecule and $\mathrm{H}-1$.
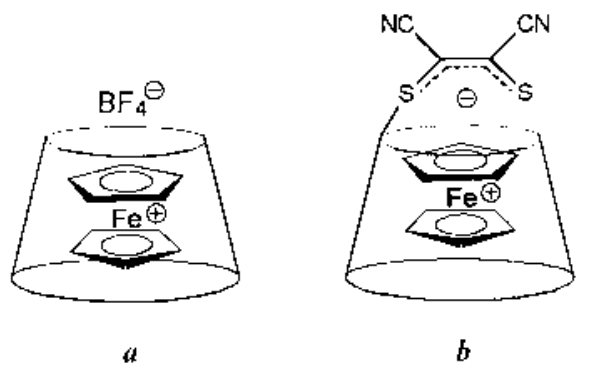

Chart 1. Proposed Inclusion Modes of Inclusion Compound $[\beta$ $\left.\mathrm{CD} / \mathrm{Fc}^{+}\right] \mathrm{BF}_{4}^{-}$(a), and Inclusion Compound 6-Mnt- $\beta-\mathrm{CD}^{-} / \mathrm{Fc}^{+}$(b)

clusion compound $6-\mathrm{mnt}-\beta-\mathrm{CD}^{-} / \mathrm{Fc}^{+}$. The signals of ferrocenium in the two inclusion compounds $\left[\beta-\mathrm{CD} / \mathrm{Fc}^{+}\right] \mathrm{BF}_{4}^{-}$ and $6-\mathrm{mnt}-\beta-\mathrm{CD}^{-} / \mathrm{Fc}^{+}$exhibited at $\delta 67.66$ and $67.65 \mathrm{ppm}$, respectively (Table 1 ).

Figure 2 showed DTG curves of pure $\mathrm{FcBF}_{4}$, pure $\beta$-CD hydrate, and the inclusion compound $\left[\beta-\mathrm{CD} / \mathrm{Fc}^{+}\right] \mathrm{BF}_{4}^{-}$. Only one peak rose in curve a at $288^{\circ} \mathrm{C}$, which was attributed to the decomposition of pure $\mathrm{FcBF}_{4}$. The two peaks (around 80 and $314^{\circ} \mathrm{C}$, respectively) in curve b corresponded to the dehydration and decomposition of pure $\beta$-CD hydrate. In curve $\mathrm{c}$, two peaks were observed, one of which (around $55^{\circ} \mathrm{C}$ ) should be assigned to the dehydration, and the other (around $318^{\circ} \mathrm{C}$ ) was related to the decomposition of $[\beta-\mathrm{CD} /$ $\left.\mathrm{Fc}^{+}\right] \mathrm{BF}_{4}^{-}$. The decomposition temperature difference between the free host and the host in inclusion compound $[\beta$ $\left.\mathrm{CD} / \mathrm{Fc}^{+}\right] \mathrm{BF}_{4}^{-}\left(\Delta \mathrm{T}_{\text {host }}\right)$ is $+4{ }^{\circ} \mathrm{C}$, and the decomposition temperature difference between the free guest and the guest in inclusion compound $\left[\beta-\mathrm{CD} / \mathrm{Fc}^{+}\right] \mathrm{BF}_{4}^{-}\left(\Delta \mathrm{T}_{\text {guest }}\right)$ is $\left.+30{ }^{\circ} \mathrm{C} .{ }^{16}\right)$ Obviously, thermal stabilities of both the host and the guest in inclusion compound $\left[\beta-\mathrm{CD} / \mathrm{Fc}^{+}\right] \mathrm{BF}_{4}^{-}$were higher than in their free forms.

DTG curves of pure $\mathrm{FcBF}_{4}$, pure 6-mnt- $\beta$-CD hydrate, and the inclusion compound $6-\mathrm{mnt}-\beta-\mathrm{CD}^{-} / \mathrm{Fc}^{+}$were shown in Fig. 3. The inclusion compound, $6-\mathrm{mnt}-\beta-\mathrm{CD}^{-} / \mathrm{Fc}^{+}$, decomposed at around $306^{\circ} \mathrm{C}$. The decomposition temperature difference between free (around $291^{\circ} \mathrm{C}$ ) and bounded 6-mnt- $\beta$ $\mathrm{CD}\left(\Delta \mathrm{T}_{\text {host }}\right)$ was $+15^{\circ} \mathrm{C}$, and the decomposition temperature 


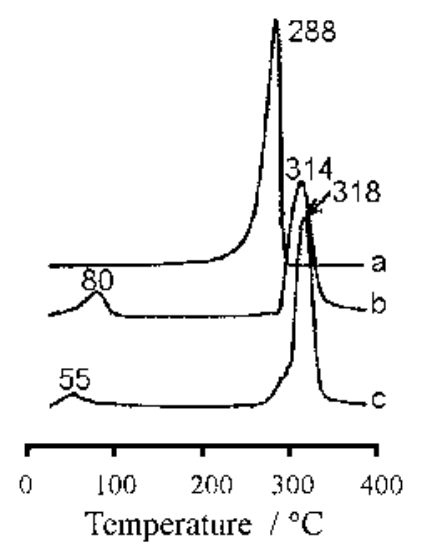

Fig. 2. DTG Curves of Pure $\mathrm{FcBF}_{4}$ (a), Pure $\beta$-CD Hydrate (b), and Inclusion Compound $\left[\beta-\mathrm{CD} / \mathrm{Fc}^{+}\right] \mathrm{BF}_{4}^{-}$(c)

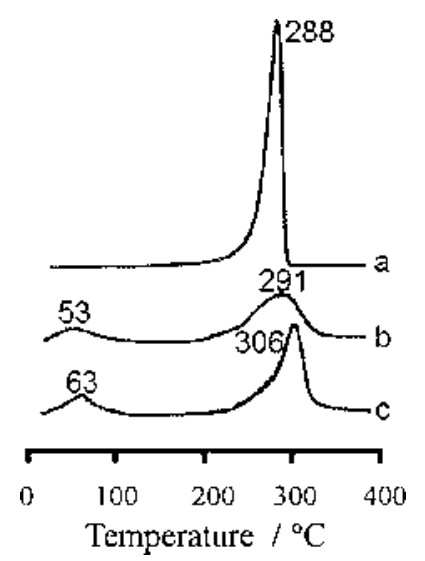

Fig. 3. DTG Curves of Pure $\mathrm{FcBF}_{4}$ (a), Pure 6-Mnt- $\beta$-CD Hydrate (b), and Inclusion Compound 6-Mnt- $\beta-\mathrm{CD}^{-} / \mathrm{Fc}^{+}$(c)

difference between free and included $\mathrm{FcBF}_{4}\left(\Delta \mathrm{T}_{\text {guest }}\right)$ was $+18^{\circ} \mathrm{C}$.

By closer inspection of Figs. 2 and 3, we came to the following conclusions: a) Compared with pure $\mathrm{FcBF}_{4}$, the inclusion complexation of both $\beta$-CD and 6-mnt- $\beta$-CD with the guest improved the thermal stability of the guest $\left(\Delta \mathrm{T}_{\text {guest }}\right.$ was $+30^{\circ} \mathrm{C}$ and $+18^{\circ} \mathrm{C}$, respectively). b) Compared with the free host, the inclusion improved the thermal stability of the host $\left(\Delta \mathrm{T}_{\text {host }}\right.$ was $+4^{\circ} \mathrm{C}$ and $+15^{\circ} \mathrm{C}$, respectively). It was interesting that a much higher $\Delta \mathrm{T}_{\text {host }}$ was achieved in 6-mnt- $\beta$ $\mathrm{CD}^{-} / \mathrm{Fc}^{+}$, which is probably due to the interaction between the side-arm anion of the host and the guest ferrocenium.

Interplay between the side-arm anion of the host and the ferrocenium in the inclusion compound $6-\mathrm{mnt}-\beta-\mathrm{CD}^{-} / \mathrm{Fc}^{+}$ was investigated by ${ }^{13} \mathrm{C}-\mathrm{NMR}$, IR, UV, and $\mathrm{CV}$ spectra (vide infra). Compared with the free host 6 -mnt- $\beta$-CD, the prominent downfield shift $(+0.48 \mathrm{ppm})$ of the nitrile groups of the side-arm in inclusion compound 6 -mnt- $\beta-\mathrm{CD}^{-} / \mathrm{Fc}^{+}$suggested some charge transfer from the mnt group to ferrocenium, which was also identified by the higher frequency shift of $v_{\mathrm{C} \equiv \mathrm{N}}$ (from 2189.7 to $2215.8 \mathrm{~cm}^{-1}$ ) in IR spectra of 6-mnt$\beta$ - $\mathrm{CD}^{-} / \mathrm{Fc}^{+}$. Further evidence in favor of this interpretation has been provided by electron spectra. An absorption maximum of 6-mnt- $\beta$-CD was blue-shifted from 385.5 to $348 \mathrm{~nm}$ after the formation of inclusion compound 6-mnt- $\beta$ $\mathrm{CD}^{-} / \mathrm{Fc}^{+}$, which revealed an electron-interaction between the

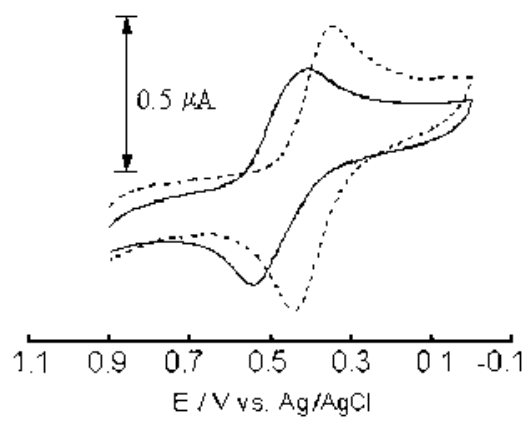

Fig. 4. Cyclic Voltammogram of $0.1 \times 10^{-3} \mathrm{M} \mathrm{FcBF}_{4}+0.1 \mathrm{M}(n-\mathrm{Bu})_{4} \mathrm{NClO}_{4}$ in DMF in the Absence (-----) and Presence (- - of $1.0 \mathrm{M} \beta$-CD Scan rate: $100 \mathrm{mV} / \mathrm{s}$

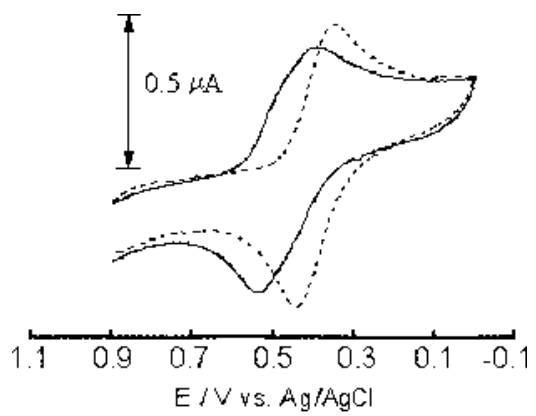

Fig. 5. Cyclic Voltammogram of $0.1 \times 10^{-3} \mathrm{M} \mathrm{FcBF}_{4}+0.1 \mathrm{M}(n-\mathrm{Bu})_{4} \mathrm{NClO}_{4}$ in DMF in the Absence (-----) and Presence (- - of $1.0 \mathrm{M}$ 6-Mnt- $\beta$-CD

Scan rate: $100 \mathrm{mV} / \mathrm{s}$.

mnt group and ferrocenium.

Effects of complexation of ferrocenium with $\beta$-CD upon the electrochemical properties were clearly evident in Fig. 4. The association constants of ferrocenium with $\beta-\mathrm{CD}$ and 6mnt- $\beta$-CD have been estimated by the solubility measurements method, ${ }^{17)}$ and were determined to be approximately $2.3 \times 10^{4}$ and $3.8 \times 10^{4}\left(\mathrm{dm}^{3} \mathrm{~mol}^{-1}\right)^{2}$, respectively. In addition, a $10^{4}$-fold molar excess of host was added to the DMF solution of ferrocenium in our experiments to ensure that the guest would work as the corresponding inclusion compound. Electrochemical behavior of the DMF solution of inclusion compound $\left[\beta-\mathrm{CD} / \mathrm{Fc}^{+}\right] \mathrm{BF}_{4}^{-}$retained the same reversible shape as $\mathrm{FcBF}_{4}$ itself, but the peak potentials were displaced toward more positive potentials by approximately $+80 \mathrm{mV}$. Compared with pure $\mathrm{FcBF}_{4}$, a substantial decrease of the peak currents in the inclusion compound $\left[\beta-\mathrm{CD} / \mathrm{Fc}^{+}\right] \mathrm{BF}_{4}^{-}$ was observed. This decrease was caused by the fact that the charged species, $\left[\beta-\mathrm{CD} / \mathrm{Fc}^{+}\right] \mathrm{BF}_{4}^{-}$, is more bulky and more slowly diffusing than $\mathrm{FcBF}_{4}{ }^{18)}$ The $+80 \mathrm{mV}$ shifts of potentials in $\mathrm{CV}$ is probably because the neutral ferrocene produced by reduction was strongly bound with the hydrophobic cavity of $\beta-\mathrm{CD}$ moiety in the inclusion compound $[\beta-$ $\mathrm{CD} / \mathrm{Fc}^{+} \mathrm{BF}_{4}^{-}$. In other words, $\mathrm{Fc}^{+}$is easier to reduce in the presence of $\beta$-CD because its reduced form, $\mathrm{Fc}$, is more strongly bound with $\beta$-CD than $\mathrm{Fc}^{+}$by itself. ${ }^{17)}$

For the inclusion compound, 6-mnt- $\beta-\mathrm{CD}^{-} / \mathrm{Fc}^{+}$, its $\mathrm{CV}$ resembled that of pure $\mathrm{FcBF}_{4}$ (Fig. 5). But compared with pure $\mathrm{FcBF}_{4}$, positive shifts $(+68 \mathrm{mV})$ of potentials were observed. The host, 6 -mnt- $\beta$-CD, has an anion side-arm which could interact with cation guest and finally stabilize the metallocenium. So compared with that in $\left[\beta-\mathrm{CD} / \mathrm{Fc}^{+}\right] \mathrm{BF}_{4}^{-}$, the guest 
ferrocenium was more difficult to reduce to ferrocene in the inclusion compound $6-\mathrm{mnt}-\beta-\mathrm{CD}^{-} / \mathrm{Fc}^{+}$. Consequently, in the $\mathrm{CV}$ of $6-\mathrm{mnt}-\beta-\mathrm{CD}^{-} / \mathrm{Fc}^{+}$, positive shifts of potentials were only $+68 \mathrm{mV}$. And in the $\mathrm{CV}$ of $\left[\beta-\mathrm{CD} / \mathrm{Fc}^{+}\right] \mathrm{BF}_{4}^{-}$, bigger potential shifts $(+80 \mathrm{mV})$ of potentials were obtained.

Generally speaking, inclusion complexation made improvements in the physical and chemical properties of the ferrocenium drug. It was known that ferrocenium is stable in aqueous acid but decomposes in a basic even neutral solution to give ferrocene and iron hydroxides in the presence of $\mathrm{O}_{2}{ }^{19)}$ After inclusion, the ferrocenium guest used here was thermally more stable than its pure form. Furthermore, the inclusion compounds of $\left[\beta-\mathrm{CD} / \mathrm{Fc}^{+}\right] \mathrm{BF}_{4}^{-}$and $6-\mathrm{mnt}-\beta$ $\mathrm{CD}^{-} / \mathrm{Fc}^{+}$were stable in an aqueous solution even at $\mathrm{pH}=13$ in the air. All of these can improve the pharmaceutical actions of the ferrocenium drug.

Acknowledgments This project was supported by the National Natural Science Foundation (No. 29771017, No. 29831010) and the State Education Commission of China.

\section{References}

1) a) Köpf-Maier P., Köpf H., Neuse E. W., Angew. Chem., Int. Ed. Engl., 23, 456-457 (1984); b) Idem, J. Cancer Res. Clin. Oncol., 108, 336-340 (1984); c) Idem, Ger. Offen. DE 3,404,443 (Cl. C07F17/02), 08 Aug. 1985, Appl. 08 Feb. 1984, pp. 22; d) Köpf-Maier P., Z. Naturforsch., C: Biosci., 40C, 843-846 (1985).

2) a) Dori Z., Gershon D., Scharf Y., Fr. Demande FR 2,598,616 (Cl. A61K31/12), 20 Nov. 1987, US Appl. 862,804, 13 May 1986, p. 13; b) Köpf-Maier P., Prog. Clin. Biochem. Med., 10, 151-184 (1989); c) Ward S. G., Taylor R. C., Köpf-Maier P., Köpf H., Balzarini J., De Clercq E., Appl. Organomet. Chem., 3, 491-497 (1989).

3) a) Köpf-Maier P., Klapötke T., Arzneim-Forsch., 39, 369-371 (1989); b) Popova L. V., Babin V. N., Belousov Y. A., Nekrasov Y. S., Sne- gireva A. E., Borodina N. P., Shaposhnikova G. M., Bychenko O. B., Raevskii P. M., Appl. Organomet. Chem., 7, 85-94 (1993).

4) Neuse E. W., Kanzawa F., Appl. Organomet. Chem., 4, 19-26 (1990).

5) a) Szejtli J., "Cyclodextrin Technology," ed. by Davis J. E. D., Kluwer Academic, Dordrecht, The Netherlands, 1988; b) Frömming K.-H., Szejtli J., "Cyclodextrin in Pharmacy," Kluwer Academic, Dordrecht, The Netherlands, 1994.

6) a) Szejtli J., Osa T. (eds.), Compr. Supramol. Chem., 3 (1996); b) D'Souza V. T., Lipkowitz K. B. (eds.), Chem. Rev., 98 (1998).

7) Albers E., Miller B. W., CRC Crit. Rev. Ther. Drug Carrier Systems, 12, 311-337 (1995).

8) Bähr G., Schleitzer G., Chem. Ber., 90, 438-443 (1957).

9) Matsui Y., Okimoto A., Bull. Chem. Soc. Jpn., 51, 3030-3034 (1978).

10) Hendrickson D. N., Sohn Y. S., Gray H. B., Inorg. Chem., 10, 15591563 (1971).

11) Lu C. S., Hu C. J., Yu Y., Meng Q. J., Chem. Pharm. Bull., 48, 56-59 (2000).

12) Song L. X., Meng Q. J., You X. Z., J. Organomet. Chem., 498, C1C5 (1995).

13) Endo T., Nagase H., Ueda H., Kobayashi S., Nagai T., Chem. Pharm. Bull., 45, 532-536 (1997).

14) Klinger B., Rihs G., J. Inclusion Phenom. Mol. Recognit. Chem., 10, 255-265 (1991).

15) a) Harada A., Takahashi S., J. Chem. Soc., Chem. Commun., 1984, 645-646; b) Harada A., Hu Y., Yamamoto S., Takahashi S., J. Chem. Soc., Dalton Trans., 1988, 729-732.

16) Yilmaz V. T., Karadag A., Icbudak H., Thermochim. Acta, 261, 107118 (1995).

17) Wu J. S., Toda K., Tanaka A., Sanemasa I., Bull. Chem. Soc. Jpn., 71, 1615 -1618 (1998).

18) Strelets V. V., Mamedjarova I. A., Nefedova M. N., Pysnograeva N. I., Sokolov V. I., Pospisil L., Hanzlik J., J. Electroanal. Chem., 310, 179-186 (1991).

19) a) Prins R., Korswagen A. R., Kortbeek A. G. T. G., J. Organomet. Chem., 39, 335-344 (1972); b) Wilkinson G., J. Am. Chem. Soc., 74, 6146-6147 (1952). 